\title{
The Relationship between Followership Style and Job Performance in Botswana Private Universities
}

\author{
Christianah O. Oyetunji ${ }^{1}$ \\ ${ }^{1}$ Limkokwing University of Creative Technology, Botswana \\ Correspondence: Christianah O. Oyetunji, Limkokwing University of Creative Technology, Botswana. E-mail: \\ ctoyetunji@yahoo.co.uk
}

Received: November 23, 2012 Accepted: December 4, 2012 Online Published: January 17, 2013

doi:10.5539/ies.v6n2p179 URL: http://dx.doi.org/10.5539/ies.v6n2p179

\begin{abstract}
This paper describes the followership style and job performance in Botswana private universities. Attempt was made to determine if there is a significant relationship between followership styles in relation to job performance. A total of 102 randomly selected lecturers from the two private universities completed followership and job performance questionnaires. The data indicates that in Botswana private universities: (a) followership styles include passive, alienated, pragmatist and exemplary followership styles. The most common followership style among the lecturers is pragmatist followership style. (b) there is no relationship between exemplary, pragmatist and alienated followership styles and job performance; indicating low performance of lecturers who indicated these followership styles. (c) there is a high relationship between passive followership style and job performance; indicating high performance of lecturers who indicated this style of followership.
\end{abstract}

Keywords: followership style, job performance, private universities in Botswana

\section{Introduction}

Success or failure of organizations, including educational institutions, is a result of both the leaders and followers' roles (Avolio \& Reichard, 2008). Research shows that followers' role though not recognized as much as leaders', account for eighty per cent of an organization's success (Kelley, 1992). As such the role of followers can no longer be ignored especially with the realization that followers actually get the job done (Kelley, 1992). Followers are as important as leaders, yet in management and organizational behaviour literature, the focus is largely on the concept of leadership (Shondrick \& Lord, 2010). However, leadership and followership co-exist, there can be no leaders if there are no followers (Kelley, 2008) yet the acceptance of followership as an important effect to leadership is fairly recent (Bennis, 2008). Dixon and Westbrook's (2003) findings validated Kelley's idea of the existence of followership in all organizational levels. It is believed that a focus on followership will enhance our understanding of the leadership process because the operation of each is dependent on the other (Henry, 2012).

Banutu-Gomez (2004) maintains that in order for leaders to succeed they must teach their followers how to lead and how to be good followers. This is important because leaders and followers are interdependent (Henry, 2012); the role of the latter influences the former. It is therefore necessary to promote good followership behavior in order to achieve educational goals.

In higher educational institutions, lecturers work hand in hand with heads of departments. Both parties are expected to work toward accomplishing educational goals. Generally, lecturers' responsibilities include the actual teaching, setting, administering and marking of students' assignments, tests papers, examination scripts and term papers, monitoring students' progress and the like. In these responsibilities, lecturers are usually left to function independently, carry out these duties with little or no supervision. The heads of departments' roles are more of administrative duties. Lecturers are closer to students and are expected to produce good results. However, they need the support of heads of departments to be very effective. It is therefore necessary that heads of departments are aware and understand lecturers' followership styles in order for them to know the best approach to use in working with lecturers for maximum effectiveness.

The study of followership as a field within the organizational management is relatively new thus more research is needed (Kellerman, 2008). Though models and theories on followership have been developed, for 
organizations to understand the influence of the followers, theories need to be translated into practice within organizational settings. The purpose of this research therefore, is to approach followership theory through direct application of followership styles in an organizational setting in order to determine if evidence actually supports the use of those styles as a means of improving organizational effectiveness.

Kelley's $(1988,1992)$ idea of followership, which is described in the subsequent section of this paper, was one of the earliest works on followership as a concept. Kelley's work is regarded as a very important contribution to followership literature (Blanchard, Welbourne, Gilmore \& Bullock, 2009). As a result of the cardinal place that Kelley's work occupies in followership literature and his observation that it is necessary to assess followership styles of people within different cultures because different cultures may produce different followership styles and behaviours (Kelley (1992), this research paper focuses on followership styles in private universities in the Republic of Botswana and draws the implications of these styles on the respective institutions and the national educational goals. In addition, effort is made to come up with useful information for administrators and leaders of these universities on followership styles and job performance. Findings from this study will also enable heads of departments, the management, academic and non-academic staff of these universities to be in a better position to identify staff members who need higher levels of partnership and support. This will go a long way in creating a more effective means of lecturers' empowerment and collaboration between them and their heads of departments.

\section{Conceptual Framework}

\subsection{Followership Style}

The empirical research reported in this paper is based on Kelley's (1992) theory of followership, one of the most important contributions in the followership literature (Blanchard et al., 2009).

According to Kelley (1992) two dimensions describe the way that people follow. The first dimension is independent, critical thinking, versus dependent, uncritical thinking. Followers who are independent, critical thinkers consider the impact of their actions on the organization, they are willing to be inventive and offer constructive criticism in spite of the consequences (Mushonga \& Torrance, 2008). Dependent, uncritical thinkers on the other hand go by the leader's thinking and do what the leader tells them to do.

The second dimension is active versus passive behavior. Active followers normally take initiatives in decision making and accomplishing tasks without constant direction or feedback from the leader and participate actively in performing their duties (Blanchard et al., 2009) and other activities in the organization. They do more than their job requires, they go an extra mile in achieving goals (Rothbard, 2001) leading to increased job satisfaction and commitment (Schaufeli \& Bakker, 2004). Passive followers on the other hand, wait to be told what to do.

Based on the two dimensions stated above which describe characteristics of followers with different levels of thinking and engagement, Kelley (1992) identified five basic styles of followership that depend on how high or low the rank on the two dimensions is: alienated, passive, conformist, pragmatist and exemplary followers.

Kelley's (1992) model portrays alienated followers as nonconformists. They are competent but cynical (Bjugstad, Thach, Thompson, \& Morris, 2006). Although they are independent and critical thinkers, they are passive in their roles. They rank high on independent and critical thinking but low on active engagement. Alienated followers do not have a sense of belonging, they feel neglected by the organization, and therefore they see themselves as outsiders. They feel that they are being used by the organization without being recognized for their contributions. Alienated followers do not hide their feelings, they openly express their disapproval of ideas they do not agree with and direct their displeasure and negative attitudes toward the organization on a regular basis (Kelley, 1992). Alienated followers are susceptible to job dissatisfaction which may lead to high absenteeism, theft, low organizational commitment, low motivation, and low performance.

Unlike alienated followers, passive followers are dependent, uncritical thinking individuals who take a passive approach within the organization. Passive followers rank low on both independent and critical thinking and active engagement. They depend on leaders to do the thinking for them. They are unenthusiastic set of people who require constant supervision to complete assigned tasks. They are neither creative nor ambitious and are more likely to experience job fatigue (Kelley, 1988). For this reason, passive followers represent ineffective followers. It is typical of passive followers to avoid situations or tasks that require or force them to engage in independent thinking. In addition, they do not put in extra time to complete given tasks; they leave whether or not they have completed tasks when the day is over. Passive followers are prone to being easily swayed by manipulative leaders because they lack the courage to defend themselves or the organization. 
The conformist followers are the ,yes people of the organizations. They are active participants in the organization's work but do not demonstrate critical thinking skills, they follow orders to the letter (Bjugstad et al., 2006). Conformists are comfortable in their job and guard against an unfriendly work environment by maintaining their boundaries because they believe it is counterproductive to the organization (Collinson, 2006). They are prepared to do everything possible to keep a good relationship with the leader. As a result, they carry out orders without questioning or thinking. Conformist followers rank low on independent and critical thinking but rank high on active engagement. Although they are efficient in doing assigned tasks, they require constant feedback from leaders. Like passive followers, conformists lack enthusiasm, self-confidence, creativity, initiative, courage, and ambition. Conformists are loyal to the organization and believe that leaders and the organization have their interest at heart. They are therefore prepared to give up or compromise their own needs to satisfy the organization.

Compared to alienated, passive and conformist followers, exemplary followers are independent, critical thinkers, innovative and willing to question the leadership. Exemplary followers rank high on both independent and critical thinking and active engagement. This type of follower is vital to organizational success because this followership style is ideal in many ways. Exemplary followers consider the consequences of tasks before they carry them out and excel in all tasks. They treat everyone in the organization the same way, get along very well with their colleagues (Bjugstad et al., 2006), provide support and intelligent criticism to the leader and even withdraw their support from an incompetent leader without disrupting the organization's operations. They stand to serve the best interest of the organization. Exemplary followers are likely to function very well in self-managed teams. They are a manager's best asset in the sense that they complement the leaders' efforts and can be depended upon to relieve the leader of many tasks (Mushonga \& Torrance, 2008).

Pragmatic followers are average in their independence, engagement and general contribution to the organization. They exhibit characteristics of the above four followership styles. Thus, they use the style that is appropriate to the prevaling situation which also benefits them and not the organization. They rarely question a leader's decisions, but do it covertly when they do. They perform the required tasks, but seldom do more than expected. When the organization is going through difficult situation, pragmatic followers do everything which is needed to get them through the crisis and not necessarily the organization. This characteristic is also affirmed by Lussier and Achua, (2010).

Kelley (1988) proposes four crucial characteristics that distinguish effective from ineffective followers. One of the characteristics is the followers' ability to determine own goals within a large context and to decide on the role to perform at a particular time to facilitate the achievement of organizational goals. A followers' demonstration of unique commitment to the organization and to a purpose beyond personal level, differentiates good from bad followers. A strong desire and effort of followers to attain higher levels of competence and to direct their efforts for utmost result distinguishes effective from ineffective followers. Another difference between effective and ineffective followers is that the latter exhibit courage, honesty, enthusiasm, intelligence and self-reliance. Unlike ineffective followers who withhold information, effective followers share their opinions. It is to the advantage of the organization if followers' thoughts are known and problems are not covered. Exemplary followers share all the attributes of effective followers.

\subsection{The Concept of Job Performance}

Job performance has become the most important focus of administrators and academicians as one of the ways of improving effectiveness in the organization and schools respectively (Fauzilasalley, 2011). Job performance can be referred to as the duties and responsibilities that are performed as part of an individual's job assignments (Vigoda, 2000). It reflects organization performance (Gomez-Mejia, Balkin, \& Cardy, 2007) and has become one of the significant indicators of organizational performance (Wall et al., 2004). Job performance is classified into 'will-do' and 'can-do'. The former refers to individuals' knowledge, skills, abilities, and other characteristics needed to perform certain jobs and the latter indicates the level of motivation individual may have in performing their work (Schmitt \& Chan in Motowidlo, 2003).

As mentioned earlier, lecturers perform a whole lot of duties. They deal directly with students' many issues. For an educational institution to achieve its goals, lecturers need to be exemplary followers in order to carry out their duties efficiently so that the set goals could be achieved in record time. For example, in the case of the Republic of Botswana, every sector is working towards realizing the nation's long term vision. The nation of Botswana visualizes among other things, a safe and secure nation, an educated and informed nation, a moral and tolerant nation, a prosperous, productive and innovative nation by the year 2016. The nation believes that a high quality education is central to the nation's vision for the future. The educational aspect of the vision is the nation's 
production of sufficient quality manpower, competent intellectuals in various disciplines to compete at international level by 2016 (Presidential Task Group, 1997). All other things being equal, the realization of the educational aspect of the vision is dependent on the effectiveness of tasked with teaching both in secondary schools and tertiary institutions.

\section{Methodology}

\subsection{Research Questions}

This paper examines the relationship between followership style and job performance of lecturers in Botswana's private universities.

- What are the followership styles of lecturers in Botswana private universities?

- Is there a significant relationship between followership style and job performance of lecturers in Botswana's private universities?

\subsection{Participants}

A total of 102 lecturers from the two Botswana private universities participated in this study. Many of the lecturers have master's degree in areas of specialization. Majority of them have put in three years and above in their current place of work. At least $95 \%$ of the lecturers in each of these universities are nationals of Botswana. A randomly selected 102 lecturers from different faculties responded to followership and job performance questionnaires.

\subsection{The Instruments}

Data were collected through the use of Kelley (1992) followership style questionnaire and Williams and Anderson (1991) job performance questionnaire. Kelley's 20-item of followership questionnaire and Williams and Anderson's 4-item of in-role performance questionnaire were used to measure followership styles and self-perception on one's job performance respectively. Subjective measure of performance in tapping job performance is most appropriately measured based on task related and behavioral aspects. Most importantly, subjective measure allows researchers to generalize the findings to a larger performance construct (Wall et al., 2004). The internal consistency reliability of the scale was (Cronbach alpha $=0.76$ ).

\subsection{Data Collection}

A total of 102 questionnaires were distributed to randomly selected lecturers in the two private universities (51 questionnaires for each of the universities). 94 questionnaires were returned from the two universities. However, only 88 valid questionnaires $(86 \%)$ were usable for data analysis. The participants responded to 20 items on followership style and 4 items on job performance.

\section{Results}

Table 1. Followership styles used by Botswana private universities lecturers

\begin{tabular}{lll}
\hline \multirow{2}{*}{ Followership Style } & Commonly use styles & \\
& $(\mathrm{N}=88$ & \\
& Common/frequency & $\%$ \\
\hline Pragmatist & 56 & 63.6 \\
Alienated & 12 & 13.6 \\
Exemplary & 11 & 12.5 \\
Passive & 9 & 10.2 \\
\hline
\end{tabular}

Table 1 provides information about the followership styles of all the participants. Frequency and percentage were used to identify the lecturers' followership styles. The majority $(63.6 \%)$ of the participants acted as pragmatist follower, $13.6 \%$ of the participants acted as alienated follower, $12.5 \%$ of them were exemplary followers and $10.2 \%$ were passive followers.

The first research question was: What are the followership styles of lecturers in Botswana private universities? The answer to this question is that Botswana private universities lecturers' followership styles were passive, alienated, pragmatist and exemplary. None of the participants indicated conformist followership style. 
Table 2. Correlation matrix for followership styles and performance

\begin{tabular}{llc}
\hline \multirow{2}{*}{ Variables } & \multicolumn{2}{c}{$\begin{array}{c}\text { Performance Target Achieved } \\
\text { (N= 88) }\end{array}$} \\
\cline { 2 - 3 } Passive & $\mathbf{R}$ & Sig \\
Alienated & .744 & .021 \\
Pragmatist & .292 & .383 \\
Exemplary &. .284 & .040 \\
\hline
\end{tabular}

According to Connolly and Sluckin (1962) the $\mathrm{r}$ value of $0.90-1.00$ shows the positive and strong relationships, $0.70-0.90$ shows a good relationships, $0.40-0.07$ shows the moderate relationships, $0.20-0.40$ shows the low relationships and the value less than 0.2 shows the weak relationships.

The second question was: Is there a significant relationship between followership style and job performance of lecturers in Botswana private universities? In addressing this question, it was transformed to the following hypotheses.

Ho: There is significant relationship between exemplary followership style and job performance.

Ho: There is no significant relationship between passive, alienated and pragmatist followership styles and job performance.

In response to the second question, as shown in Table 2, exemplary followership style $(r=.214, p>0.05))$ was not related to job performance and the relationship was not significant. This means that exemplary followers were not high performers. Thus the hypothesis that exemplary followers are always expected to be high performers is rejected.

The results reveal that passive followership style was highly correlated to job performance $(r=.744, p<0.05)$ and the relationship was significant. This indicates that lecturers who claimed to be passive followers were high performers. Alienated followership style $(r=.292, \mathrm{p}>0.05)$ was not related to job performance, the relationship was not significant. Pragmatist followership style $(r=-.284, p<0.05)$ was not related to job performance, the unrelatedness was significant. This suggests that alienated and pragmatist lecturers' job performance was low. This means that the hypothesis which states that: there is no significant relationship between passive, alienated and pragmatist followership styles and job performance is accepted for alienated and pragmatist followership styles but rejected for passive followership style.

\section{Discussion}

As mentioned earlier, according to Kelley's (1992) theory, pragmatist followership style is eclectic, it takes a little of conformist, alienated, passive and exemplary followership styles. The findings of this study revealed that $63.6 \%$ of the lecturers were in the category of pragmatist followers. The implication of this is that many lecturers are average in independent, critical thinking and engagement. This suggests that many lecturers in Botswana private universities are merely doing the minimum to get themselves sustained on their jobs, and they are not all that passionate about the vision of the organization and that of the nation itself. Incidentally, in the Republic of Botswana, the government among other people is counting on public and private universities lecturers in realizing the nation's orchestrated and highly valued vision.

Based on Kelley's (1988) idea of effective and ineffective followers' characteristics, pragmatist followers fall under ineffective followers because they share ineffective followers' characteristics as enumerated above. Because lecturers who act as pragmatist followers are ineffective they cannot positively drive the nation's vision. The improvement of education standards in Botswana and or the achievement of the nation's vision require lecturers to do more than what is required of them. The nation's vision requires exemplary lecturers who are prepared to go an extra mile in order to achieve educational goals that are enshrined in the nation's vision. This research shows that such exemplary lecturers are not there. The knowledge of this situation, its acknowledgement and the readiness on the apart of the government to quickly address the situation will go a long way in ensuring the realization of the vision

According to Kelley's (1992) theory alienated followers are aloof to the organization because they do not feel appreciated by the organization. They are competent but they do not use their competence for the good of the 
organization. The findings of this study indicate that $14 \%$ of the participants are in this group. It can be inferred that some lecturers do not get themselves actively involved in organization's activities. This is because they hardly see anything good in the organization, they use their judgemental comments and unenthusiastic attitudes to discourage other lecturers from performing their roles. They expend their energy on negativity and it is most likely that these lecturers have a negative influence on the students. They may incite students to go against the school management through their careless comments since they hardly see good things in what the school management does. Because they are not happy with the management, they are not likely to enjoy their job. Consequently, they will not have the interest of students at heart and may not do their primary assignment as expected. This set of lecturers in Botswana private universities does not benefit the education system especially now that Botswana is trying to salvage the deteriorating educational standards (Molefe, Pansiri, \& Weeks, 2011). Besides, the pressure is mounting as the year 2016, the projected time to achieve the nation's vision approaches. This anomaly needs the urgent attention of the relevant authorities in Botswana.

Going by Kelley's (1992) theory because exemplary followers are committed to the organization and go all out to facilitate its achievement, they are effective. The findings indicate that $12.5 \%$ of lecturers in Botswana private universities who participated in the study are in this group. This category of lecturers does more than their job requires. They do their work with enthusiasm. They attend their classes regularly because they are passionate about their students' progress. They are active in staff meetings and willingly contribute constructively to meetings. They are quick to come up with solutions where there are lapses. Exemplary lecturers give all their support to the management. They do not wait for heads of departments to tell them what to do. They are committed to the course they believe in. Their students are their priority, they go out of their way to assist their students and make sure they learn what they need to learn, for instance, they give their time to their students even when it is not convenient for them.

This group of lecturers (exemplary followers) is what Botswana tertiary institutions need to achieve educational goals. They are the ones the country can rely on to improve education standards and to realize its vision in a few years to come. However, with the majority of the sampled lecturers acting as pragmatist followers, the vision cannot be accomplished unless the situation is quickly arrested. The improvement of education standards and production of sufficient quality manpower, competent intellectuals in various disciplines to compete at international level (Presidential Task Group, 1997), may become a mirage if necessary step is not taken by the relevant authorities to change the attitude of lecturers in Botswana private universities.

Kelley's (1992) theory suggests that passive followers are passive, dependent, uncritical thinking workers who are ineffective. The findings from this study reveal that $10 \%$ of the participants are in this group. The implication of this is that some lecturers are neither competent nor active. This suggests that this category of lecturers cannot be trusted to give their students quality content if they are not closely supervised. These lecturers also contribute to the declining standard of education (Kayawe, 2012). With these lecturers in the classroom the nation's vision on education is far from being materialized because they have next to nothing to offer the students. These lecturers find opportunities to dodge work, thus sometimes neglecting their primary duty - teaching the students.

The results of correlation of predictor variables with job performance however, suggest that lecturers who were passive followers were high performers in this study. This finding did not establish the main characteristics of passive followers as proposed by Kelley (1992). It is not clear why lecturers who claimed to be passive followers are the high performers in this context. The negative relation between alienated style of followership and job performance is in support of Kelley's (1992) proposition. Because of their wrong perception of the management they are aloof and unhappy, thus their work suffers. Pragmatist followership style was not related to job performance and the unrelatedness was significant. Pragmatist followers are supposed to have moderate job performance level (Lussier \& Achua, 2010), but in this case they were performing far below expectation.

In contrast to existing literature, exemplary followership style was unrelated to job performance. Exemplary lecturers' job performance was very low. It was expected that lecturers who claimed to be exemplary followers would demonstrate a difference in level of job performance compared to other followership styles identified among lecturers. In other words, exemplary followers should demonstrate higher level of job performance than passive, pragmatist and alienated followers. Lecturers who claimed to be exemplary followers were not exemplary because the level of their job performance was comparable to other lecturers who identified themselves as alienated and pragmatist followers. If indeed they were exemplary followers their job performance level should be exceptional, it should challenge other lecturers. Because they are committed to the organization and look beyond themselves, their activities should have positive impact on the organization. The hypothesized significant relationship between exemplary followers and job performance was not supported. 
The passive followers had the highest level of job performance while the exemplary followers' job performance level was very low. One possible explanation for this kind of finding is that lecturers had a wrong perception of their followership styles and job performance. Lecturers who claimed to be exemplary may be vocal and appear to be active but may not focus on the main business of the organization. Those who claimed to be passive probably got the job done because they were constantly supervised by their superiors.

The majority of lecturers claimed to be average performers (pragmatist followers) but their job performance was low. In other words, many lecturers in Botswana private universities have not been performing to expectation. An average performance is not good enough to bring the nation of Botswana to the level where it can compete internationally. Below average performance of the majority of the lecturers in Botswana private universities is an indication that the nation's vision may not be realized at the set time unless corrective measures are quickly put in place.

Theoretically, exemplary followership style can bring about desired improvement in the organization performance. If heads of departments are only responsible for $20 \%$ of the work in the institution (Kelley, 1992) then all effort should be directed to teaching lecturers to be exemplary followers. This is important not only for heads of departments to succeed as leaders (Banutu-Gomez, 2004) but also to restore and improve education standard. Lecturers who indicated alienated, passive and pragmatist followership styles cannot bring about the improvement needed in education standard. It is the exemplary followers who can build a positive relationship with other lecturers and their heads of departments, the kind of relationship that encourages every member to concentrate on the goals of the institution. They are the followers who can motivate other lecturers to aspire to excel in their job. These are the kind of lecturers that the relevant authorities in Botswana need to ensure are in the nation's private universities if the nation's vision is to be realized.

\section{Conclusions and Implications}

The results of this study indicate that the followership styles of Botswana private universities are: passive, alienated, pragmatist and exemplary. The majority of lecturers who participated in this study indicated pragmatist followership style. Alienated, pragmatist and exemplary followership styles were not related to job performance indicating low performance of lecturers who indicated these followership styles. Passive followership style was highly related to job performance indicating high performers of lecturers who claimed to be passive followers.

Although job performance of lecturers who indicated exemplary followership style was low, exemplary followership characteristics are not only desirable but are also said to be responsible for the improvement of organization performance and achievement of its goals. Based on these findings, the heads of departments in Botswana private universities should be knowledgeable about different followership styles and they should identify the followership styles among their lecturers. Leaders (heads of departments) in Botswana private universities need to forgo their self-preoccupation which can limit their understanding of lecturers and eventually limit effectiveness (Collinson, 2006). It is time heads of departments in Botswana private universities begin to give sufficient attention to lecturers, understand them so as to know the areas where lecturers need support. In Botswana private universities, heads of departments' knowledge of lecturers' followership styles will help them to identify lecturers that need to be taught desirable characteristics associated with exemplary followers.

Since heads of departments depend on lecturers for the success of the institution, it is imperative for the heads of departments in Botswana private universities to make conscious effort to recognize and promote exemplary followership characteristics among lecturers. Relatively among African countries, Botswana has demonstrated enviable development over the years. The nation has taken giant strides in socio-political and economic development. Her political stability and prudent management of resources has earned the country a reputable place in Africa. For Botswana therefore, vision 2016 is a milestone in forging ahead and also in consolidating past and present gains. Findings from this research will go a long way in sensitizing the relevant authorities in Botswana on some of the issues that are worthy of note in realizing her educational goals as enshrined in vision 2016. Further study is needed to examine factors responsible for high performance of lecturers who indicated passive followership style and low performance of lecturers who claimed to be exemplary followers.

\section{References}

Avolio, B. J., \& Reichard, R. J. (2008). The rise of authentic followership. In R. E. Riggio, I. Chaleff \& J. R. Lipman-Blumen (Eds.), The art of followership: how great followers create great leaders and organizations. (pp.55-73). San Francisco: Jossey-Bass. 
Banutu-Gomez, M. B. (2004). Great leaders teach exemplary followership and serve as servant leaders. Journal of American Academy of Business, 2(1/2), 143-150.

Bennis, W. (2008). The Art of Followership: How great followers create great leaders and organizations. (I. C.-B. R. E. Riggio, I. Chaleff \& J. R. Lipman-Blumen (Eds.). San Francisco CA USA Jossey-Bass.

Bjugstad, K., Thach, E. C., Thompson, K. J., \& Morris, A. (2006). A Fresh Look at Followership: A Model for Matching Followership and Leadership Styles. Journal of Behavioral and Applied Management, 7(3), 304-319.

Blanchard, A. L., Welbourne, J., Gilmore, D., \& Bullock. A. (2009). Followership Styles and Employee Attachment to the Organization. The Psychologist Manager Journal. Retrieved from http://www.tandfonline.com/doi/abs/10.1080/10887150902888718

Collinson, D. (2006). Rethinking followership: A post-structural analysis of follower identities. The Leadership Quarterly, 17(2), 179-189. Retrieved from $\mathrm{http} / /$ www.sciencedirect.com/science/article/pii/S104898430500175X

Connolly, T. G., \& Sluckin, W. (1962). An Introduction to Statistics for Behavioral Science. Second Edition. London: Cleaver-Human Press.

Dixon, G., \& Westbrook, J. (2003). Followers Revealed. Engineering Management Journal, 1, 19-25.

Fauzilah, S., Noryati, Y., \& Zaharah, D. (2011). The influence of skill levels on job performance of public service employees in Malaysia. Business and Management Review, 1(1), 31-40.

Gomez-Mejia, L. R., Balkin, D. B., \& Cardy, R. L. (2007). Managing Human Resources. NJ: Pearson Education International.

Henry, B. C. (2012). Leadership models for effective change management. International Journal of Computer Science and Management Research, 1(4), 817-819.

Kayawe, B. (2012). BGSCE results: a sad reality. The Monitor, 13(7), 8.

Kellerman, B. (2008). Followership: How followers are creating change and changing leaders. Bolton: Harvard Business Press.

Kelley R. E. (2008). Rethinking followership. In R. E. Riggio, I. Chaleff \& J. R. Lipman-Blumen (Eds.), The art of followership: how great followers create great leaders and organizations (pp.5-16). San Francisco: Jossey-Bass.

Kelley, R. E. (1988). In Praise of Followers. Harvard Business Review, 66(6), 142-148.

Kelley, R. E. (1992). The Power of Followership. New York, NY: Doubleday.

Lussier, R. N., \& Achua, C. F. (2010). Leadership: Theory Application \& Skill Development $4^{\text {th }}$ Edition USA: Cengage Learning.

Molefe, M., Pansiri, O., \& Weeks, S. (2011, March 14). Issues in Education. The Monitor, 12(10), 6.

Motowidlo, S. J. (2003). Job performance. In W. C. Borman, D. R. Ilgen \& R. J. Klimoski (Eds.), Handbook of Psychology: 12 Industrial and Organizational Psychology (pp.39-53). NY: John Wiley and Sons.

Mushonga, S. M., \& Torrance, C. G. (2008). Assessing the relationship between followership and the Big Five factor model of personality. Review of Business Research, 8, 185-193.

Presidential Task Group. (1997). Vision 2016: Towards Prosperity for All. Gaborone: Government Printer.

Rothbard, N. P. (2001). Enriching or depleting? The dynamics of engagement in work and family roles. Administrative Science Quarterly, 46, 655-684. Retrieved from http://www.jstor.org/discover/10.2307/3094827?uid=3738720\&uid=2132\&uid=2\&uid=70\&uid=4\&sid=21 101575882567

Schaufeli, W. B., \& Bakker, A. B. (2004). Job demands job resources and their relationship with burnout and engagement: A multi-sample study. Journal of Organizational Behavior, 25, 293-315. Retrieved from http://onlinelibrary.wiley.com/doi/10.1002/job.248/abstract;jsessionid=8CB005ABFC793865BCF00D554C C81E63.d02t02

Shondrick, S. J., \& Lord, R. G. (2010). Implicit leadership and followership theories: dynamic structures for leadership perceptions, memory, and leader-follower processes. In G. P. Hodgkinson \& J. K. Ford (Eds.), 
International Review of Industrial and Organizational Psychology (pp. 1-34). Birmingham, UK: Wiley-Blackwell.

Vigoda, E. (2000). Internal politics in public administration systems: An empirical examination of its relationship with job congruence, organizational citizenship behavior, and in-role performance. Public Personnel Management, 29(2), 185-210.

Wall, T. D., Michie, J., Patterson, M., Wood, S. J., Sheehan, M., Clegg, C. W., \& West, M. (2004). On the validity of subjective measures of company performance. Personnel Psychology, 57(2), 95-118.

Williams, L. J., \& Anderson, S. E. (1991). Job satisfaction and organizational commitment as predictors of organizational citizenship and in-role behaviors. Journal of Management, 17(3), 601-617. 